\title{
Kashmir Conflict: A Case for UN Intervention
}

Javaid Ahmad Dar ${ }^{1}$

${ }^{1}$ Assistant Professor of Economics, Government Degree College, Kokernag, Anantnag (J \& K), India

Email: mailtojavaiddar@gmail.com

\begin{abstract}
The study explores the causes and consequences of Kashmir conflict which has always been an impediment in the development of both India and Pakistan. It begins with a brief discussion on the cause of the issue and its international recognition. The paper then explains Article 370 and its implications to India and Pakistan. Then the author discusses in detail the cases of displacement of Kashmiri Pundits and the human rights violations in the conflicted area. The respective perspectives of India and Pakistan on the issue are also discussed and the author critically analyses possible solutions to the issue, proposed by the United Nations and other international authorities. The author then concludes the study by throwing light on the significance of the UN intervention in the permanent solution of the issue. The author then concludes the study by proposing demilitarization of the disputed area on both sides of border, followed by unification of the whole region and then conducting a UN supervisedarea wise plebiscite of the whole territory, as the most acceptable and realistic solution to the decades old conflict.
\end{abstract}

Keywords: Conflict, human rights violation, The United Nations, Article 370, plebiscite

\section{The Conflict}

Kashmir is considered to be the most perilous place to live in as it is the Centre of nuclear flashpoint between India and Pakistan. Before 1947, Kashmir was a Princely State but this issue of conflict started just after the British left India in 1947. There were more than 600 princely states before 1947 including Kashmir. The viceroy of India at that time, Lord Mountbatten, advised these princely states to accede to either India or Pakistan. These princely states acceded to either of the two countries on the basis of geographical location and communal interests. India and Pakistan laid claim on Hindu majority states and Muslim majority states respectively, but India rejected Pakistan's claim on Kashmir, although eighty percent of the population in Kashmir was Muslim. Maharaja Hari Singh was the last king of independent Kashmir and his delay in making decision about accession of Kashmir proved to 
be the root cause of the conflict. He wanted Kashmir to remain a princely state, but in the mean time a tribal invasion took place which was backed by Pakistani raiders, the king felt insecure and decided to seek military help from India. Lord Mountbatten promised him the military help and in return Maharaja Hari Singh signed "The Instrument of Accession to India" on October 26, 1947. The accession letter signed by Hari Singh did not mark end to the conflict, Pakistan aggressively claimed Kashmir as its territory, as a result the valley got divided into two parts, Indian administered Kashmir and Pakistan administered Kashmir. The instrument of accession in itself is controversial as it was conditional. Afterwards, Maharaja Hari Singh and Jawaharlal Nehru agreed that after the restoration of normalcy, the issue will be solved according to the wishes of the people through a plebiscite. In January, 1948 India took the issue to the United Nations where Kashmir was declared a disputed territory hence giving an international recognition to the issue. The United Nations recognized the right to self determination of the people of Kashmir and advised India and Pakistan to resolve Kashmir issue according to the wishes of the people. India began efforts to drag the issue down, and under various pretexts tried to stop the UN resolution from being implemented. To this day, India pursues the same plan and the resolution of 1948 is yet to be realized. On the other hand, Pakistan has been raising the issue at all forums and using all its intelligence and international influence to pressurize India to implement the UN resolutions on Kashmir, hence always keeping it as a burning issue. In 1947, Sheikh Abdullah was made the Prime Minister of Kashmir and the state was given a special status according to Article 370 of Indian Constitution.

\section{Figure 1: Shows the line of Control/divided of the state of Jammu and Kashmir}

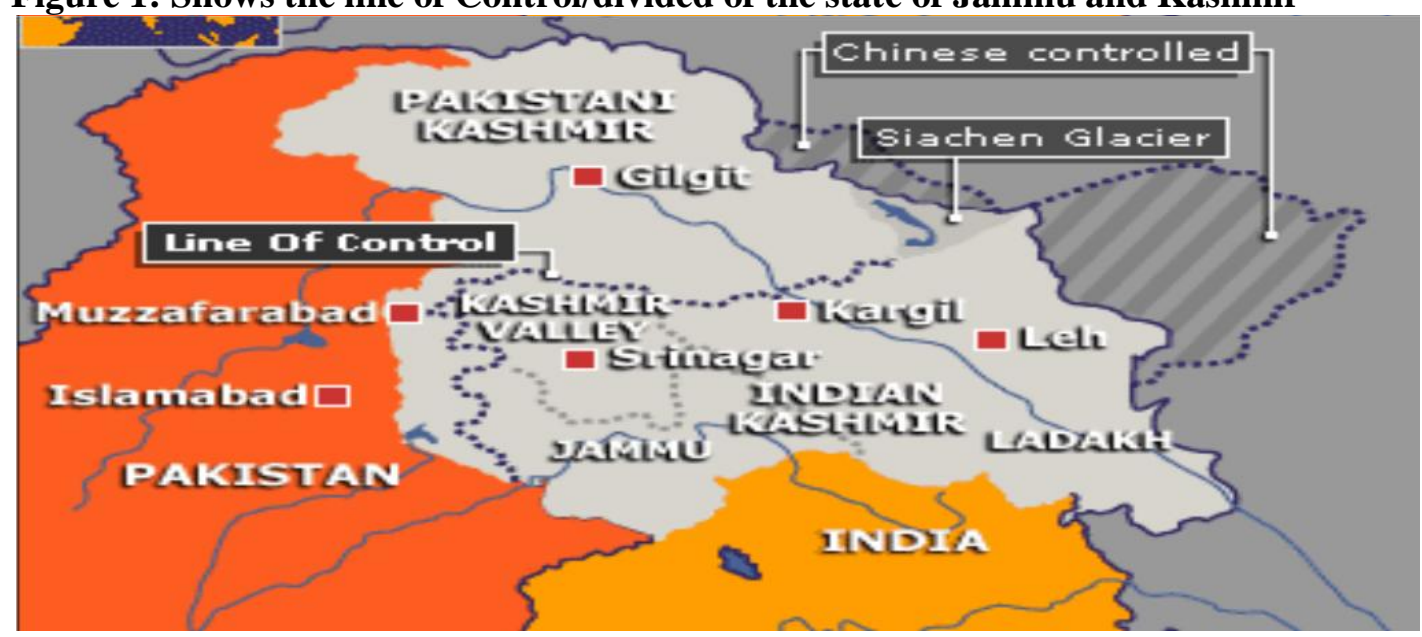




\section{Article 370}

The constitution of India came into force on $26^{\text {th }}$ January, 1950 with Article 370 giving special status to Jammu \& Kashmir. The special status given to the state meant that while being a part of India the people of Jammu \& Kashmir lived under different law. Article 370 which are labeled as temporary provision, allow the constitutional difference between Jammu \& Kashmir and the rest of Indian states. Article 370 has three clauses. Clause (1) states that article 238 is not applicable to Jammu \& Kashmir, thus giving Indian parliament power to make laws for Jammu \& Kashmir only on the matters of defense, communication, finance and external affairs, only after consultation or by order of the state government. Clause (2) required that any concurrence given by the interim government of Jammu \& Kashmir must be placed before the assembly for decision. Clause (3) of Article 370 states that the president can issue a mare notification to restrict the operation of this article only on the recommendation of the constituent assembly of the state. According to this Article, except finance, defense, foreign affairs, and communications, the Parliament of India needs the concurrence of the state government for applying all other laws. Thus the residents of Jammu $\&$ Kashmir live under a separate set of laws, related to citizenship, ownership of property, and fundamental rights, as compared to rest of the Indians. As a result of this provision, Indian citizens from other states cannot purchase property or land in Jammu \& Kashmir and the Centre has no power to declare financial emergency under Article 360 in the state. Indian government can declare emergency in the state only in case of external aggression. The central government therefore, cannot declare emergency on grounds of imminent danger or internal disturbance or unless it is made at the request or with the concurrence of the state legislature.

The foremost implication of Article 370 is the legislative exception of Jammu \& Kashmir. There are still various legislations that do not apply to the state of Jammu \& Kashmir as the consultation between the union government and the state government failed. The Indian Penal Code, 1860, which is the most comprehensive legislation on criminal law in India and also adopted by many other countries operates in whole India except Jammu \& Kashmir. The Prevention of Corruption Act, 1988, The Applicability of the Religious Institutions Act, 1988, Delhi Special Police Establishment Act, 1946 and other acts are not applicable to Jammu \& Kashmir. According to this article the non residents of Jammu \& Kashmir cannot buy land or property in the state, hence becoming an obstacle in the inflow of private investment to the state by non residents (rest of Indians). Kashmir still remains the 
most vital issue between India and Pakistan and the communal forces in these two countries are making it a bone of contention. It is in this backdrop that the current Prime Minister of India Mr. Narendra Modi gave a call for debating the article 370, a hell broke loose. His intention in saying ' who it has benefited' was to indicate that it is unnecessary and should be abolished. Abolition of the article is an integral agenda of RSS-BJP's parent organization. But the separatists as well as the mainstream politicians of the state are warning of dare consequences. The chief minister of Jammu \& Kashmir said that if India anyhow abolishes Article 370, this will mark end to the accession of state to India as Article 370 is the only legal link between India and Jammu \& Kashmir. It is true that in Kashmir today there are many tendencies, which vary from asking for total independence, Azadi to Autonomy and Self Rule. There will hardly be any popular support for debating or abolishing article 370 as such at broad layers. It is very difficult to say how many fall in which category, but a large number are for more autonomy, with article 370 in place.

\section{The Displacement of Kashmiri Pandits}

The term Kashmiri Pandits refers to the Kashmiri Hindus living in the valley from ancient times. The Hindus and Muslims of Kashmir used to live in an atmosphere of cultural unity which they commonly referred to as "Milchaar". They followed same code of conduct, shared common practices, wore same dress, spoke same language, but followed their respective religions. Although Kashmiri pandits were small in number, but the community was playing a significant role in the society as they were highly educated and closely related with the administration and courts, making them a highly visible group. The worst communal scenario in India in 1980's added as a fuel to the fire of militancy in Kashmir, the harmony prevalent in Kashmir received a communal touch. Some state as well as some non-state actors took advantage of the situation and targeted Pandits for their political motives. This resulted in an atmosphere of fear and insecurity for the pandits. Although, pandits were not in favor of leaving their homes, but the governor of Jammu \& Kashmir, Mr. Jagmohan, was more interested in evacuating the Pandits from the valley to deal with the militants in a different manner. Some popular Pandits were targeted by militants and at the same time Jagmohan got support from some Hindu communal forces in spreading terror and fear in the minds of Kashmiri Pandits. Rumors were spread in Delhi and other parts of the country that Hindu shrines and temples have been destroyed in the valley, although it was strongly condemned by the Muslim community to the hilt, especially the separatists. Some rumors were spread that the militants have made a hit list of prominent pandits for execution. Some Pandits were also 
threatened through posters, letters, telephone calls and advertisements in the print media. A Srinagar based newspaper ALSAFA, on $14^{\text {th }}$ April, 1990 published an ultimatum given by HIZBUL MUJAHIDEEN stating, "All Pandits should leave the valley in two days". The authenticity of these ultimatums was not known. Because of some selective killings, the spread of rumors, and the encouragement given by Jagmohan and other communal minds, the Pandits left the valley to refuge in Jammu and other parts of the country. However, we cannot underestimate the role of turmoil but it was not pandit specific. A large number of Muslims were killed and some were forced to leave their homes. Even pandits are aware of the fact that the first victims of militancy were the Muslims. According to the figures published by government of Jammu \& Kashmir in March, 2010, the number of pandits targeted by militants from 1989 to 2004 was 219, out of which 122 casualties happened between January, 1989 and December, 1990 and from 2004 there is no report of such a killing. ${ }^{1}$ However we cannot be mindless in neglecting more than a lakh of Muslims killed, and only considering pandits as the victims of militancy. The government also played a negative role as it supported the migration of Pandits rather than assuring their safety.

Initially, militancy was dominated by Jammu and Kashmir Liberation Front (JKLF), the organization which was fighting for self determination and the Hindu community didn't feel threatened. In fact, some pandits also supported the cause of separatism and were advocating Kashmiri nationalism. When militancy started in 1989, pandits supported the separatists and participated in anti-India processions. There was no hostility between the two communities but security forces were involved in gross human rights violations. This led to the mass migration of Kashmiri pandits and hence a serious setback to the tradition and culture of Kashmir. The issue of Kashmiri Pandits leaving the valley is very much controversial as there are contradicting explanations for their mass exodus. Most of the Kashmiri Pandits believe that they were forced to leave but they never reached a consensus as to who forced them out. Some of the pandits blame the whole Muslim community of Kashmir while others blame only the armed militants who they suppose were fully backed by Pakistan. Now the condition is improving in Kashmir and even the separatists have assured full security to Kashmiri pandits ${ }^{2}$. Syed Ali Shah Geelani, the chairman of All Parties Huriyat Conference

\footnotetext{
${ }^{1}$ Shujaat Bukhari: "219 Kashmiri Pandits killed by militants since 1989", The Hindu, March 24, 2010 .

The author gives comprehensive report on the number of Kashmiri Pandits leaving the valley and of those killed by the militants and the rehabilitation schemes run by the government.

2 The Economic Times, 12 July (2012).
} 
(APHC) has assured Kashmiri pandits that all the Kashmiri Muslims would protect them if they return to Kashmir ${ }^{3}$. But he opposed the creation of separate colonies for them as he believed that the government is using these colonies to rehabilitate non-Kashmiri Hindus for changing the ethnic composition of the valley. Geelani said that Kashmir have never opposed the return of pandits, but will always be against creating separate zones for them as it is an attempt to divide Kashmir on religious lines. It would be worth noting that a pandit woman was elected as a Panchayat member from "Wusan", a village in north Kashmir where more than $98 \%$ of voters are Muslims, indicating the liberal nature of Kashmiri Muslims. Now the pandits have also realized the changes and are returning to the valley.

\section{The Case of Human Rights Violations}

Kashmir is experiencing a large scale human rights violation which is largely unaddressed. The human rights activists and organizations have not been able to act proactively and punish the human rights violators-Army, police and militants. Custodial killings, torture, rapes and fake encounters are continuously increasing. For all kinds of armed forces in the valley the human rights violation has become a norm, as they have been powered with underscoring impunity. The agitations of 2008 and 2010 are the representatives of the cases where innocent civilians were tortured and unarmed protestors were fired upon and killed. These human rights violations are protected by some unpopular laws like Armed Forces Special Powers Act (AFSPA), Disturbed Areas Act (DAA) and Public Safety Act (PSA), giving the armed forces unlimited powers to shoot arrest and kill, along with other heinous acts. According to KASHMIR MEDIA SERVICE, a local news agency, following is the update of violence between 1989 and 2010 in Kashmir.

Table 1

\begin{tabular}{|c|c|}
\hline Parameter & Value \\
\hline Total killings & 93,389 \\
\hline Custodial killings & 6,974 \\
\hline Civilians arrested & 118,060 \\
\hline Structures destroyed & 105,866 \\
\hline Women widowed & 22,734 \\
\hline Children orphaned & 107,366 \\
\hline Women gang-raped/Molested & 9,946 \\
\hline
\end{tabular}

As the data suggests, Kashmir has witnesses a large scale custodial deaths ever since the armed struggle started in the valley. Most of the cases follow the same pattern but are

\footnotetext{
${ }^{3}$ Greater Kashmir, 18 July (2012).
} 
mostly executed by the forces serving India ${ }^{4}$. Usually the civilians, who are supposed to help the militants or have knowledge about militants, are detained and tortured and in some cases, even killed. ${ }^{5}$

One of the horrifying consequences of the armed struggle and heavy deployment of armed forces in the valley is that most of the people in detention of the Indian armed forces go missing. Most of the missing persons are men, hence making the women to live life of Half Widows. ${ }^{6}$ The international human rights law confides the disappearances at the hands of the government as enforced disappearances. But the police never entertain any kind of a missing report of these persons. Association of Parents of Disappeared Persons (APDA), from a long time has been demanding the whereabouts of custodial disappeared persons by various security agencies, mostly since 1988, but all in vain. Although the organization has been continuously highlighting their demand and sufferings, but their grievances and genuine pleas are yet to be addressed. According to the International Convention on Enforced Disappearances (ICED), under any condition whatsoever (war, threat of war, political instability or other emergency); the state is obliged to investigate the cases of forced disappearances. Still the cases of forced or enforced disappearances are unaddressed in the valley.

Rape is a heinous crime. This crime has been used in the conflicted regions to humiliate a community and destroy their honor. For a rape victim, usually the stigma never goes away, and the victim remains shunned and shamed for the whole life. Since the armed struggle began in Kashmir in January 1990, the frequency of the reports of rapes by Indian paramilitary forces have increased drastically. We do not find much reliable statistics of rapes committed by Indian security forces and militants in Kashmir, as most of the cases have happened in the remote areas of the valley, and conform the precise data in such cases become almost impossible. Some human rights groups of India and the international media

\footnotetext{
${ }^{4}$ AMENESTY INTERNATIONAL in 1995 reported 706 custodial killings between 1990 and 1994, but government of India responded to only 519 cases and reported rest of the cases as encounter killings without any supporting evidence and despite of contrary reports of the eye witnesses.

${ }^{5}$ On april 26, 1993, THE KASHMIR TIMES published a police record which mentioned that more than 132 people had been killed in custody in the preceding 32 days.

${ }^{6} \mathrm{HALF}$ WIDOW is a term given to women whose husband have been disappeared during ongoing armed conflict in Kashmir. Beyond the daily bloodshed and behind the headlines about the ongoing conflict, a large section of Kashmir' s female population has been suffering silently. It is thought that the husbands of more than 1,500 Kashmiri women have disappeared, condemning their wives to a life in limbo. Known as "half-widows", they have been left in a male-dominated society with little government protection - because they cannot confirm whether their men are dead or alive.
} 
has highlighted the rape cases by Indian armed forces in Kashmir but this issue has not received much international condemnation. Only a couple of such cases have received international attention and the security forces were not punished in those cases also.

On the intervening night of 23 and 24 February, 1991, more than 23 women were raped in Kunan Poshpora village of north Kashmir by Indian army troops during a search operation. According to reports, at around $11 \mathrm{pm}$, more than a hundred Indian army troops entered the village and segregated men and women. The men were taken to a nearby field and the women were made to stay inside their houses. Then the troops entered the houses and gang raped the women from age 13 to 80 . Till now, perpetrates are roaming free and no action was taken against them. If such kind of an incident taken place in any other state of India, there would have been too much public outcry and agitation on a large scale, and the human rights organizations and judiciary would have also taken an active part.

The Shopian rape and murder case is one of the most publicized rape cases in Kashmir, which lead to severe controversy and mass protests. According to local people of Nagbal Shopian, on May 29, 2009 Asiya Jan (17) and Nelofer Jan (22) went to their apple orchard in the village from where they were forcibly taken by the men in uniform, and then gang raped and murdered. After the recovery of the bodies, Shopian district and the whole valley was on fire, protests, stone pelting and clashes with the men in uniform dominated the headlines of the newspapers. The saga of lies, obfuscation and cover ups by police and the government began just after the recovery of the bodies. Complete shutdown was observed in the entire valley for ten days and Shopian district remained closed for 47 days against mishandling of the investigation, still the accused were freed without any charge.

Hundreds of unidentified graves have been found in Kashmir, which are supposed to be of the victims of unlawful killings by Indian army and other forces serving India. The International People's Tribunal On Human Rights And Justice In Indian-Administered Kashmir (IPTHRJ) released a report on December 2, 2009. The tribunal investigated some graves in Kupwara, Baramula and Bandipura districts and found 2700 unknown and mass graves $^{7}$ which contained 2943 bodies. All these were killed and buried in the ongoing conflict, between 1990 and 2009. Most of these graves are believed to be of the victims of illicit killings committed by the Indian Paramilitary Forces during the conflict. But the government of India is continuously insisting that the mass graves contain the bodies of foreign militants

\footnotetext{
${ }^{7}$ A mass grave is a grave containing more than one, and unidentified human cadaver. Most of the scholars define mass graves as which result from human rights violation, war crimes and genocide.
} 
who infiltrated in the valley. On 26 August, 2011 the State Human Rights Commission (SHRC) also confirmed the presence of mass graves in the valley. The security forces branded the killings as the foreign militants which were handed over to the local people for burial. The State Human Rights Commission (SHRC) has been demanding to form a committee consisting of the representatives of the entire localities, to investigate and to collect samples for DNA tests. But the government authorities and military officers have refused to allow the DNA testing of the bodies, fearing that it may lead to popular mass uprising and attract international media attention. In the recent past also, hundreds of such unidentified bodies were proved to be of innocent local villagers.

The military-civilian ratio in Kashmir is 1:20, the highest in the world. It means that there is one soldier for every 20 civilians in the valley, making it the most militarized area in the world.

There are more than 5 lakh soldiers, 3 lakh army men, 70 thousand RR soldiers and 1 lakh and 30 thousand central police personnel for a total population of one crore. In the last two decades, Kashmir's one generation has grown with soldiers at every corner, (Times Of India, June 13, 2010). The grievance of common Kashmiri is that instead of fighting against the foreign aggression and militants, the military and other paramilitary forces are suppressing the common people. The excessive militarization thus has wiped out the available space of democratic and human rights for the people, and has resulted in the terrorization of the common masses. In Kashmir, The Armed Forces (Special Powers) Act, 1958 has been in force since 1987. This act gives the armed forces special powers to fire upon or use force (which may even lead to death) against any person, or arrest any person without warrant and enter and search any premises without any prior permission. The unlimited powers to the military have resulted in illegal arrests, torture, rape, custodial deaths and disappearances of innocent people. Another law which was passed to tackle the protests is Jammu and Kashmir Public Safety Act, 1978. This law is also draconian in nature, does not meet international human rights standards and has been continuously misused by the security forces. Most of the prisons in Jammu \& Kashmir are full of the people which have been arrested under Public Safety Act (PSA), including some minors. On various occasions, PSA is slapped on the same person more than once, at successive periods of two years, hence making the detention period longer. In the recent past, some human rights organizations and some civil organizations along with all Kashmiri's have raised their voice at all forums for the removal of all the draconian laws from the valley. 


\section{India's Perspective on Kashmir Issue}

New Delhi's core claim on Kashmir issue is that the instrument of accession signed by Maharaja Hari Singh with the government of India is "totally legal and final, not disputed", regardless of the circumstances in which it was signed. According to India, the only "unfinished business" of the partition is to free Pak occupied Kashmir that Pakistan illegally occupies. India maintains that the United Nations resolutions (calling for a plebiscite) are not tenable as Pakistan has retained a part of Kashmir which it occupied through aggression, thus violating the precondition of the resolutions. India further maintains that Pakistan has attempted to alter the status quo by means of military action in 1965 and 1999, thus forfeited the right to invoke the United Nations resolutions. The will of the people of Jammu and Kashmir need not to be ascertained through a plebiscite. According to India, the Kashmir problem is the problem of terrorism directly sponsored by Pakistan. India is ready to solve all outstanding issues with Pakistan through dialogue, excluding Kashmir issue, as it is India's internal issue and is directly related to the integrity of India.

India's Kashmir policy operates at three levels: local level, bilateral level and international level. India's main goal at the local level is to crush the Kashmiri separatism and resistance by the use of paramilitary forces and intelligence agencies on the one hand and by manipulating the differences among the separatists, other resistance groups and religious leaders on the other.

At the bilateral level (Indo-Pak level), India has always expressed its willingness to solve all outstanding issues with Pakistan, but has always avoided any sort of dialogue with Pakistan that would contradict with India's position that Kashmir is an integral part of India. India's main purpose of maintaining some sort of dialogue with Pakistan is to consolidate its position in Kashmir by crushing the resistance, independent analysts also believe that "since India already occupies a larger and most important part of Kashmir and knowing the difficulty that it would face in trying to pry militarily strong Pakistan loose the rest of Kashmir by military action, India would accept the conversion of LOC into the international boundary. ${ }^{8}$

India's policy on Kashmir issue on the international level primarily revolves around four things: Deflecting the campaign run by Pakistan for the implementation of UN resolutions; hiding the Human rights violations by Indian forces in the valley; emphasizing

\footnotetext{
${ }^{8}$ See Rebert G. Wirsing, India, Pakistan and the Kashmir Dispute: On Regional Conflict and It's Resolution. (New York: St. Martin's Press, 1994), p.219-220
} 
Pakistan Journal of Humanities and Social Sciences, 5(1), 2017

that the Simla agreement is the only solution to Kashmir issue; and branding Kashmiri resistance movement as "an Islamic terrorist movement" sponsored by Pakistan.

\section{Pakistan's Perspective on Kashmir Issue}

According to Pakistan, Jammu and Kashmir has always been a disputed territory. The accession of the state to India in 1947 was provisional, not permanent, and executed under the pressure of Indian army. The UN Security Council resolutions of 13 August, 1948 and 5 January, 1949 acknowledge Jammu and Kashmir the status of a disputed area, which was accepted by both India and Pakistan. The UN resolutions are applicable even today and cannot be disregarded by either of the country. ${ }^{9}$

1) The dialogue between the two countries over the future of Jammu and Kashmir should focus on securing the right of self-determination for the people of Kashmir. This very right entails an internationally sponsored plebiscite recommended by United Nations Security Council in 1948 and 1949 resolutions, signed by both India and Pakistan.

2) The plebiscite should offer the choice of permanent accession to India or Pakistan to the people of Jammu and Kashmir.

3) The dialogue between the two countries regarding the future status of Jammu and Kashmir should confirm the UN Security Council resolutions. A third party mediatory role may be appropriate. Pakistan has always considered Kashmir as "The Lifeline of Pakistan" .

\section{The Politics of Resources: Pakistan's Secret Policy}

The location of Kashmir is very strategic for both India and Pakistan but water resources are the most important reason of Pakistan's interest in Kashmir. Pakistan has always considered Kashmir as "The Lifeline of Pakistan", by taking economic point of view. One can understand the fact by analyzing the speech of Hafiz Saeed ${ }^{10}$ on 16th of September, 2003. He maintained in his speech that most of the rivers which flow through Pakistan originate from Indian administered Kashmir. So the only way for Pakistan to save its economy in the future is to get the control of the water resources in Indian administered Kashmir. Sardar

\footnotetext{
${ }^{9}$ Ijaz Hussain, Kashmir Dispute: An International Law Perspective. (Rawalpindi: Services Book Club, 2000), Ch.V.

The author defends the continued validity of UN resolutions to Kashmir Issue with valid arguments.

${ }^{10}$ Hafiz Muhammad Saeed, born in 1950, is currently the head of the Jama'at-ud-Da'wah, actually a charity organizationbut is widely considered to be a cover organization for one of the deadliest terror groups Lashkar-e-Taiba. Hafiz Saeed, is accused of planning and executing the 26/11Mumbai terror attacks with the help of ISI. Under Saeed's watch, LeT has grown to become a terror group that rivals al-Qaida in its reach and lethality. Times of India, April 4, 2012.
} 
Mohammad Anwar Khan, the former president of Azad Kashmir, once said in a public forum that the economy of Pakistan is directly dependent on the water resources of Jammu and Kashmir. Sikander Hayat, the former Prime Minister of Pakistan, in a seminar on 3rd March, 2003 even went to say that Pakistan will turn into a desert if it does not acquire the water resources of Jammu and Kashmir. So the people who are fighting for freedom in Kashmir are actually fighting for safeguarding the interests of Pakistan. The four rivers, Sind, Jhelum, Chenab and Ravi are the main source of drainage system for Pakistan. All the four rivers originate from Indian administered Kashmir and by the natural lay of land, they flow to Pakistan. Most of the agricultural production in Pakistan depends directly on the water resources of these four rivers, making Kashmir the lifeline of Pakistan. Mohammad Ali Jinnah, the founder of Pakistan considered Kashmir as the Jugular Vein of Pakistan. Out of the five rivers that flow to Pakistan, four of them originate from Indian administered Kashmir. India and Pakistan signed a treaty in 1960 regarding the distribution of water between the two countries, but Pakistan does not trust India and believes that India can any time block the water, which India has never done till date. The Indus Water Treaty of 1960 signed between India and Pakistan, has favoured Pakistan by giving it 56\% of the catchment area while as India has been given only $30 \%$ of the catchment area. More than $80 \%$ of Pakistan's cropland is irrigated making the country having world's largest contiguous network of irrigation. So Kashmir is very important for Pakistan from both strategic point of view as well as the economic point of view. But the most unfortunate part of Pakistan's Kashmir policy is that they want to hijack Kashmir only through cross border terrorism and violation of ceasefire on the Line of Control. Pakistan does not want peace in Kashmir and wants Kashmir to be always in news. The only way to grow for the two siblings of South Asia (India and Pakistan) is to leave aside the narrow-mindedness and have a positive approach towards the long lasting solution of the issue, otherwise the people of the two countries would die waiting to see their country economically and socially developed and free from the menace of terrorism and communal clashes.

\section{Possible Solutions to Kashmir Issue}

Analysts have proposed a number of solutions to Kashmir issue during the last six decades. There can be four possible solutions to the issue and each solution can be expanded on a particular method. ${ }^{11}$ The possible solutions are as follows:

\footnotetext{
${ }^{11}$ Pervaiz Iqbal Cheema, Solution For Kashmir Dispute? Reginal Studies (Autumn 1986), P. 3-15
} 


\section{A. Plebiscite}

- The United Nations can hold a plebiscite for whole Jammu and Kashmir. The plebiscite should be strictly based on the commitment between Maharaja Hari Singh and the then viceroy of India, Lord Mountbatten. It is worth mentioning that the commitment of a plebiscite was always supported by the then prime minister of India Jawaharlal Nehru.

- A plebiscite can be held only in Kashmir valley under the supervision of United Nations and the rest of the area can be partitioned.

- A comprehensive plebiscite can be held under the joint supervision of India and Pakistan.

\section{B. Partition}

- Partition of Jammu \& Kashmir can be done on the basis of composition of religion, allotting Muslim majority areas to Pakistan and non-Muslim majority areas to India.

- Azad Kashmir can be integrated with Pakistan and the areas of Jammu and Ladakh can be integrated with India and a plebiscite, under the supervision of the United Nations, can be held in rest of the disputed region.

\section{Independence}

- Independent status can be awarded to whole Jammu \& Kashmir, guaranteed by India, Pakistan, United Nations and all the world powers.

- Azad Kashmir can be integrated with Pakistan and the areas of Jammu and Ladakh can be integrated with India and independent status can be accorded to the Kashmir valley, guaranteed by all, India, Pakistan, the United Nations and all world powers.

- Both Azad Kashmir and the Indian occupied Kashmir can be made the United Nations trust territories and independence can be granted to both the regions at some future date, most probably after a decade.

- Azad Kashmir can be integrated with Pakistan, Jammu and Ladakh can be integrated with India, Kashmir valley can be made a United Nations trust territory, and independence can be granted to the valley after a decade of UN rule.

\section{The Resolution of United Nations and Owen Dixon's Proposal}

The United Nations resolutions of 13 August, 1948 and 5 January, 1949, signed by both India and Pakistan, proposed the solution of Kashmir issue through a plebiscite. The

The author categorises the possible solutions to the Kashmir Issue. 
resolutions laid down some principles and procedures for free and fair plebiscite under the patronage of the United Nations. India and Pakistan signed and accepted these resolutions but later both these countries clashed over the interpretation of the clause pertaining to demilitarization of Jammu and Kashmir. In 1950, Sir Owen Dixon was nominated as the United Nations mediator by the Security Council. He proposed that the local authorities, supervised by United Nations officers, of the whole disputed region should be given the responsibility of administrative work. It was rejected by the government of India.

After India's rejection of the first proposal, Mr. Dixon asked for a coalition government for the disputed valley during the period of plebiscite. The coalition government was proposed to be made of two hitherto hostile parties: a non-political neutral administration or an executive of UN representatives. But this proposal was rejected by both India and Pakistan.

Since first two proposals were rejected by India and Pakistan, Sir Owen Dixon came up with one more alternative. Sir Dixon proposed to hold a region wise plebiscite in Kashmir valley, allocating the areas to India or Pakistan, on the basis of result of the plebiscite. Pakistan rejected the proposal, saying that India has already committed to hold a plebiscite in whole Jammu \& Kashmir. At the same time, Pakistan was ready for the partition of Jammu and Kashmir if it was given Kashmir valley, but this was not acceptable to India.

When all proposals of Sir Dixon were rejected by either of the countries, at last he came up with a new proposal which called for plebiscite for the valley, conducted by officers of the United Nations. This required complete demilitarization of the area, Pakistan rejected even this proposal. ${ }^{12}$

\section{Conclusion}

Kashmir has been a bone of contention between the two nuclear states of India and Pakistan, right since the partition. Due to its physical contiguity with both India and Pakistan, vital water resources and physical access with the Great Silk Route ${ }^{13}$, Kashmir has a great strategic, economic, geo-political and military importance for both countries. The people of both the countries are living peaceful lives but Kashmiri's are still living under the shadow of black clouds. Sixty seven years have passed and still the two countries have not reached any consensus regarding the solution of the issue. The two countries are busy in bringing up their

\footnotetext{
12 Josef Korbel, Danger in Kashmir. (New Jersey: Princeton University Press, 1966). Chapter VII The author analyses the alternatives proposed by Sir Owen Dixon.

${ }^{13}$ Ancient Economic trade route, Starts from China, runs to Europe via Central Asia
} 
stocks of nuclear weapons, and have fought three wars; at last it has always been the common Kashmiri who has suffered. Kashmir issue is still unresolved because neither India nor Pakistan is arguing logically, even the United Nations, which has confirmed the disputed status of the region, seems to be in no mood of solving the issue. The international community has a wrong notion that Kashmir issue as a border dispute between India and Pakistan, which actually is the issue of people of Kashmir- fighting for their identity. Despite the failure of United Nations in solving the Kashmir dispute, the presence of United Nations Military Observer Group in India and Pakistan (UNMOGIP) ${ }^{14}$ offices in both sides of Kashmir confirms the disputed status of the valley and the sentiment of Kashmir is that the valley is not a part of India or Pakistan but is an internationally disputed territory, hence justifying their demand for the right to self determination. Till date, various solutions have been proposed by the United Nations and other international mediators, but either of the two countries has rejected them, on the ground that it will harm their national interest. It is very important to change the mindset of the two countries, and The United Nations is the only authority that can pressurize them to reach a logical compromise. The first thing that the two countries should be asked to do is to demilitarize the region. The demilitarization of the valley will pave a way towards the solution of the long pending dispute and will not only bring the relief to the people of Kashmir but it will also initiate the political, economic and social reconstruction of the region. A true picture of democracy in any society manifests the importance of human values over the imposition of national sovereignty and so called nationalism. Hence plebiscite, a way of exercising the right to self determination, would let the people decide about their fate. In order to find a peaceful and democratic solution to the issue the people of Kashmir must be allowed to decide about their future. Economic packages and developmental programmes would only bring short term peace in the valley rather than resolving the conflict forever. After the demilitarization of the whole disputed region, the two parts of the divided state should be united. The areas under Pakistan's control (including Gilgit and Baltistan) and the areas under India's control (including Jammu and Ladakh), should be united. After the unification of the region, the United Nations should hold a region

\footnotetext{
${ }^{14}$ In January 1948, UN Security Council Resolution 39 established the UN Commission on India and Pakistan (UNCIP) to send unarmed military observers to mediate and investigate the dispute between India and Pakistan over Kashmir; these observers eventually evolved into the UN Military Observer Group in India and Pakistan (UNMOGIP). Currently 41 military observers, 23 international civilian personnel and 47 local civilian staff monitor the ceasefire. In 1971, a resurgence of hostilities in the region ended when India and Pakistan reached a ceasefire agreement that UNMOGIP monitors.
} 
wise plebiscite in which there will be no intervention of either of the countries. Different areas of the conflicted zone should be divided between India, Pakistan and a possible sovereign nation (Republic of Independent Kashmir), on the basis of result of the plebiscite. This solution will most likely be acceptable to all the three stakeholders. The possible new sovereign nation could play the role of virtual bridge between the two countries and this would clear all the obstacles in the way of peace, development and prosperity in the whole South East Asia, and would maintain the high status of international bodies like The United Nations. 
Pakistan Journal of Humanities and Social Sciences, 5(1), 2017

\section{References}

Alexander Evans, As bad as it gets: The Kashmir Insurgency, April 2000, p.3

Balraj Puri, Kashmir: Towards Insurgency, New Delhi 1993, pp.64-67.

Balraj Puri, Kashmir: Towards Insurgency, New Delhi 1993, p.63.

Bruce Lusignan, India, Pakistan, And The Kashmir Conflict: Towards A Lasting Solution, Ethics

Chari P R \& Pervais Iqbal Cheema 2003: 143

Dhingra And Arora, At The Cross Roads: Families In Distress, J. Hum. Ecol., 17(3): 217-222 (2005)

D. Suba Chandran, Is Pakistan Re-positioning itself in Kashmir? Islamabad' s Five Likely

Greater Kashmir, 18 July (2012).

Ijaz Hussain, Kashmir Dispute: An International Law Perspective. (Rawalpindi: Services Book Club, 2000), Ch.V.

Jahangir And Shafi, Status Of Human Rights In Democratic Setup: Experiences From Kashmir, Journal Of Law And Conflict Resolution, Vol. 4(3), Pp. 41-47, April, 2013

Josef Korbel, Danger in Kashmir. (New Jersey: Princeton University Press, 1966). Chapter VII

Kashmir: The View from Islamabad. International Crisis Group, December 4, 2003

Kalis and Dar, Geo-political Significance of Kashmir: An overview of Indo-Pak Relations, IOSR Journal Of Humanities And Social Science, Volume 9, Issue 2 (Mar. - Apr. 2013),

Kuldip Nayar, Kashmiri Pandits: Political games worsen their plight, Times of India, 18 April 1997

Laura Schuurmans, Mass Graves \& Human Rights Violations in Indian-held Kashmir, The International Council for Human Development \& Kashmir Council EU Brussels, September, 252012

Mahendra S Bora: Report of Independent People's Tribunal on Human Rights Violations in Kashmir, 2010

Mishra and Sajad, Human Rights Violations in Kashmir with Special Reference to Indian Paramilitary Forces, Satpuda Research Journal, 2014

M Amarjeet Singh, Conflict In Jammu And Kashmir, National Institute Of Advanced StudiesBangalore India, 2011 
Pandit, Giridhari Lal, The state of collective crimes: Beyond South Asian political ritual dynamics, World Affairs, 14 (1), 167 (2010)

Pankaj Mishra,Kashmir: The Unending War: The Human Rights Crisis In Kashmir: A Pattern Of Impunity, Human Rights Watch, April 8, 1993

Pervaiz Iqbal Cheema, Solution For Kashmir Dispute? Reginal Studies (Autumn 1986), P. 3 15

Puri Balraj, Kashmir Defending National-Cultural Identity, Economic and Political Weekly (3) 422-423 (1990).

Rashmi Sehgal, Kashmir Conflict: Solutions and Demand for Self-determination, International Journal of Humanities and Social Science Vol. 1 No. 6; June2011

Rebert G. Wirsing, India, Pakistan and the Kashmir Dispute: On Regional Conflict and It's Resolution. (New York: St. Martin's Press, 1994), p.219-220

Sandeep Waslekar, The Final Settlement Reconstructing India-Pakistan Relation, Strategic Foresight Group, Mumbai, 2005, 48.

Sheikh Abdul Hamid, Migration, Return And Rehabilitation Of Kashmiri Pandits: State Response, International Research Journal Of Social Sciences: Vol. 2(10), 7-10, October (2013)

Shujaat Bukhari: "219 Kashmiri Pandits killed by militants since 1989", The Hindu, March 24, 2010.

Strategies, IPCS ISSUE BRIEF, October 2011.

Syed Rifaat Hussain, Resolving The Kashmir Dispute: Blending Realism With Justice, The Pakistan Development Review 48 : 4 Part II (Winter 2009) Pp. 1007- 1035

Teng, M.K and Gadoo, C.L (1998) Kashmir: Militancy and Human Rights: New Delhi, Anmol Publications, P. 74

The Economic Times, 12 July (2012).

The Kashmir Times, April 26, 1993.

Times of India, April 4, 2012.

Victoria Schofield, Kashmir in Conflict, New York 2000, p.154. 